\title{
群体・上流端設置時の連結石礫の流体力評価 EVALUATION OF HYDRODYNAMIC FORCE ON CONNECTED STONE
}

\author{
前野詩朗 ${ }^{1} \cdot$ 藤原実咲 $^{2} \cdot$ 富田晃生 ${ }^{2} \cdot$ 山村 $^{\text {明 }}{ }^{3} \cdot$ 忰熊公子 ${ }^{4}$ \\ Shiro MAENO, Misaki FUJIWARA, Akio TOMITA, Akira YAMAMURA and Kimiko KASEGUMA

\begin{abstract}
${ }^{1}$ 正会員 工博 岡山大学准教授 環境学研究科社会基盤環境学専攻（干700-8530 岡山市津島中 3-1-1)
2 学生会員 岡山大学環境学研究科社会基盤環境学専攻博士前期課程（干 700-8530 岡山市津島中 3-1-1）

${ }^{3}$ 日建工学株式会社 総合技術研究所（干 160-0023 新宿区西新宿 6-10-1 日土地西新宿ビル 17F)
\end{abstract} \\ ${ }^{4}$ 正会員 日建工学株式会社 総合技術研究所（† 160-0023 新宿区西新宿 6-10-1 日土地西新宿ビル 17F)
}

\begin{abstract}
Nature friendly hydraulic structures made of natural stones such as ripraps have attracted attention in recent years. However, those structures are subject to failure problem under flood flow. Therefore, the authors proposed connected stone to increase its stability against flood flow. Coefficients such as the drag and lift force are necessary in designing those structures. However, the authorized values for those coefficients are not established yet, the coefficients used for concrete structures are therefore applied in designing structures made of stones at present condition. This study aims to clarify the drag and lift coefficient for connected stones placed at the middle and upper reach of the bed protection works using connected stones.
\end{abstract}

Key Words : nature friendly structure, natural stone, connected stone, drag coefficient, lift coefficient

\section{1.はじめに}

1990 年代から環境に配慮した「多自然型川づくり」 が全国各地で進められるようになった。しかし，実 態は，必ずしも多自然型ではない事例もあった。そ こで，より自然に近い川づくりを進める必要がある との観点から, 今後は「多自然川づくり」が展開さ れることとなった。このような背景により，自然に 優しい材料である自然石碟で構築される水理構造物 が望まれる。しかし, 石砶で構築される構造物は,

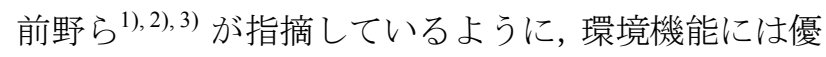
れているものの, 洪水時の破壊に対する強度不足が 懸念される.

そこで，環境機能を保持したまま河床保護機能を 高めるために, 自然石を連結する工法に関する研究

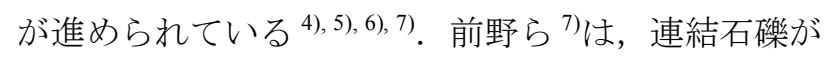
単体として設置された場合の抗力係数, 揚力係数を 明らかにしている。本研究は，従来の研究で明らか にされていなかった，連結石碟を群体として設置す る場合，また，群体中の先頭部分に設置する場合の 連結石礫に作用する流体力を分力計により計測する ことにより, 連結石砶の抗力・揚力係数を実験的に 明らかにし, めくれ, 滑動, 抜け出し破壊に関する 連結石礫の効果について検討を行った。 また, 群体 設置時については相当粗度の検討も行った.さらに,

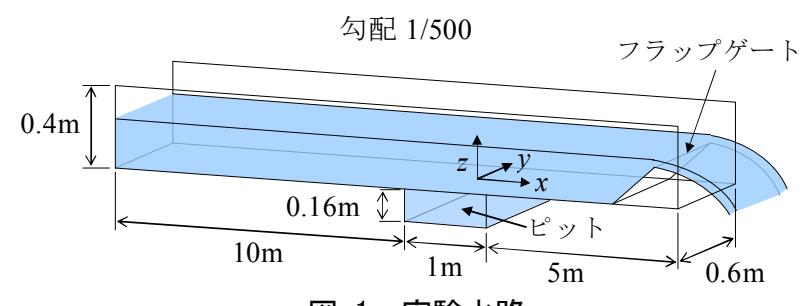

図-1 実験水路

群体試験時における流速場を計測し，連結石礫周辺 の流速変動, 流速原点位置についての検討も行った.

\section{2. 実験の概要}

実験に用いた水路は図-1 に示すような長さ $16 \mathrm{~m}$, 幅 $0.6 \mathrm{~m}$, 勾配 $1 / 500$ の循環水路である. 水路上流端 より $10 \mathrm{~m}$ の位置に長さ $1 \mathrm{~m}$, 幅 $0.6 \mathrm{~m}$, 深さ $0.16 \mathrm{~m}$ の ピットがあり, 水路下流端には水深を調節できるフ ラップゲートが設けられている.

流体力の測定には，四分力計（東京計測社製，定 格容量 : $\left.F_{x}, F_{y}, F_{z} ; 20 \mathrm{~N}, M_{y} ; 4 \mathrm{~N} \cdot \mathrm{m}\right)$ を水路ピ ット内中央部に設置した. 定格出力 $($ 最大負荷を与え た時の印加電圧 $1 \mathrm{~V}$ 当たりの出力電圧)はいずれの成 分も約 $0.5 \mathrm{mV} / \mathrm{V}$ である. 本研究では, 流体力が小さ く出力電圧も小さくなるため, $0.2 \mathrm{~N}$ 程度の載荷によ るキャリブレーションを行い精度を確認した。四分 


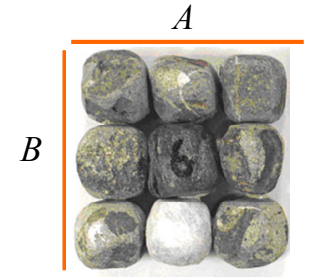

(a) 透過型

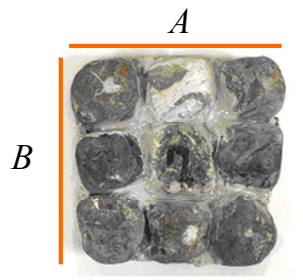

(b) 不透過型
写真-1 連結石礫模型

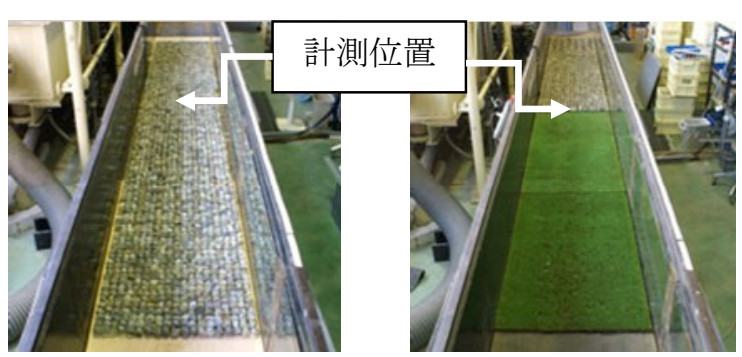

写真-2 設置状況

表-1 実験ケース

\begin{tabular}{|c|c|c|}
\hline 試験名 & 透過・不透過 & 方向 \\
\hline 群体 & $\mathrm{P} \cdot \mathrm{IP}$ & $\mathrm{A} \cdot \mathrm{B}$ \\
\hline 上流端 & $\mathrm{P} \cdot \mathrm{IP}$ & $\mathrm{A} \cdot \mathrm{B}$ \\
\hline
\end{tabular}

表-2 連結石鿬諸元

\begin{tabular}{|c|c|c|}
\hline 諸元 & 透過型 & 不透過型 \\
\hline 重量 $(\mathrm{N})$ & 3.09 & 3.16 \\
\hline $\begin{array}{c}\text { 最大寸法 }(\mathrm{cm}) \\
x \times y \times z\end{array}$ & $8.7 \times 8.9 \times 3.0$ & $9.0 \times 8.9 \times 3.0$ \\
\hline 平均高 $h_{0}(\mathrm{~cm})$ & 1.41 & 1.50 \\
\hline 抗力作用面積 $A_{D}\left(\mathrm{~cm}^{2}\right)$ & 21.23 & 20.72 \\
\hline 揚力作用面積 $A_{L}\left(\mathrm{~cm}^{2}\right)$ & 69.56 & 71.29 \\
\hline
\end{tabular}

$\mathrm{A}$ 面を上流側に向けて設置した場合
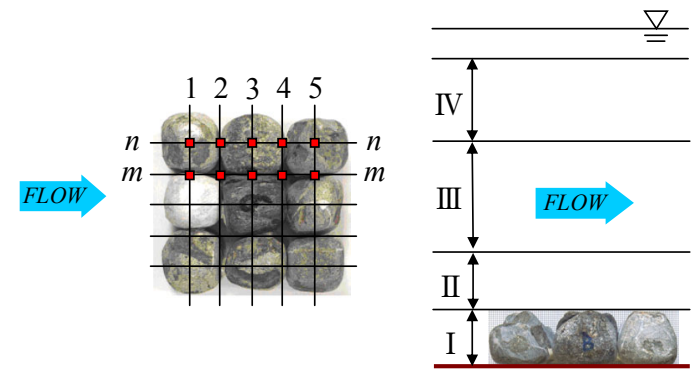

\begin{tabular}{|c|c|c|c|}
\hline & 区間長 & 測定閒隔 & 測定方法 \\
\hline I & $3.0 \mathrm{~cm}$ & $0.3 \mathrm{~cm}$ & $x, y, z$ \\
\hline II & $3.0 \mathrm{~cm}$ & $0.5 \mathrm{~cm}$ & $x, y, z$ \\
\hline III & $6.0 \mathrm{~cm}$ & $1.0 \mathrm{~cm}$ & $x, y, z$ \\
\hline IV & $4.0 \mathrm{~cm}$ & $1.0 \mathrm{~cm}$ & $x, z$ \\
\hline
\end{tabular}

図-3 流速場測定点

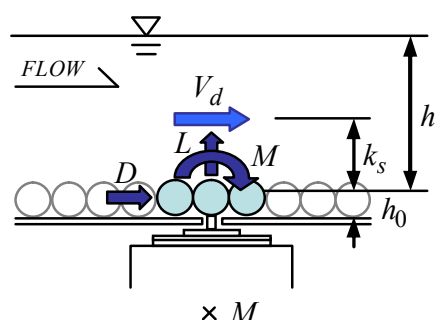

$\times M_{c}$

群体試験時

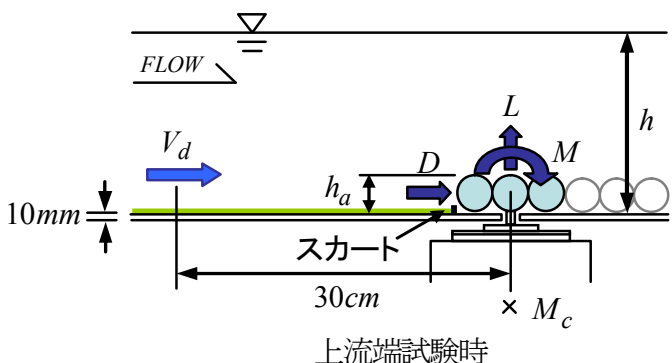

上流端試験時

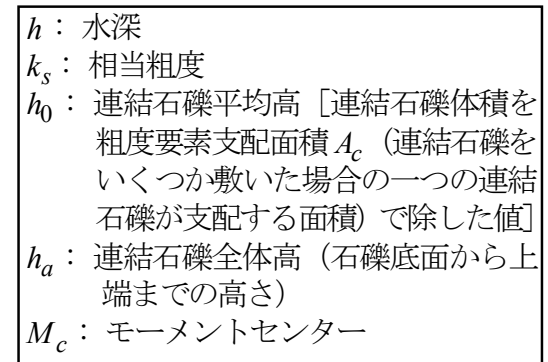

図-2 連結石碟設置状況

力計並びに石碩の設置方法は護岸ブロックの試験法 ${ }^{8}$ に 準じて行った. 実験には, 写真-1 (a)に示寸石礫間に間隙 があり透過性を有する透過型連結石碩(P: permeable)と,

写真-1 (b) に示す石㗂間に間隙がなく不透過な不透過型 連結石綑(IP: impermeable)を用いた. 石礫の敷設状況を写 真-2 に示寸.

実験ケースを表-1に示す．なお，連結石砅を構成する 個々の石礫がそれぞれ異なった形状であることを考慮し て，実験ケースとしては，写真-1 亿示寸 A，B の面をそ れぞれ上流側に向けることにより 2 方向を対象とした.

また，表-2に石硴の諸元を示す.

本実験では, 護岸ブロックの試験法 ${ }^{8}$ に準じて $1 \times 10^{4}$ 以 上のレイノルズ数 $R_{e}$ が得られる試験を 3 ケース以上含 むよう, 流量 $50,55,60,65,70 \mathrm{\ell} / \mathrm{s}$ を与えた. この時 フルード数 $F_{r}$ は 0.35 から 0.56 , 水路床から水面までの 高さは $17.93 \mathrm{~cm}$ である. 各流量について水深 $h$, 流下方 向の近傍流速 $V_{d}$, 石碩に働く流体力である抗力 $D$, 揚 力 $L$, モーメント $M$ を計測した. なお, 横断方向の作
用力は小さいため本研究では検討していない.

抗力・揚力係数, 相当粗度は下記により求めた.

- 抗力係数 $C_{D}$ ・揚力係数 $C_{L}$

$$
D=\frac{1}{2} \rho C_{D} A_{D} V_{d}^{2} \quad, \quad L=\frac{1}{2} \rho C_{L} A_{L} V_{d}^{2}
$$

ここに, $A_{D}, A_{L}$ : 抗力, 揚力作用方向の投影面積, $V_{d}$ : 近傍流速, $\rho$ : 水の密度である. ここでの近傍流速 $V_{d}$ は, 護岸ブロックの試験法 ${ }^{8}$ に準じて, 図-2 に示寸位置 の水路中央地点で計測した. なお，上流端試験において は, 石㗂底面に流れが生じないよう連結石碩上流端より $1 \mathrm{~mm}$ の地点にスカート $(x: 1 \mathrm{~mm}, y: 90 \mathrm{~mm}, z: 5 \mathrm{~mm})$ を設置した ${ }^{8)}$.

- 相当粗度 $k_{s}$ 本実験では式(2)の平均流速公式を用いて算出すること とし, 摩擦速度 $u$ *については群体試験における抗力を用 いて式(3)により算出した.

$$
\frac{V_{m}}{u_{*}}=6.0+5.75 \times \log _{10}\left(\frac{h}{k_{s}}\right)
$$




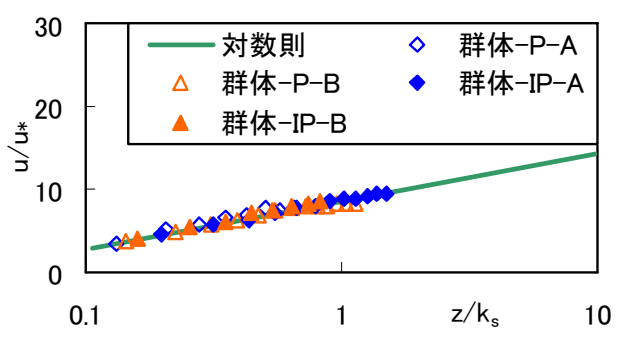

図-4 連結石磁中央上の流速分布と対数則との比較

$$
u_{*}=\sqrt{\frac{D}{\rho \cdot A_{c}}}
$$

ここに, $V_{m}$ : 平均流速である.

流速場の計測は, 図-3 に示寸ように石磎の頂点位置と 連結位置に対して鉛直方向に図に示寸(I) (IV)の鉛直区 間で計 160 点において群体透過型敷設時の流量 50l/s 時 に行った. (I)〜(III)区間でADV (NORTEK 社製: Vectrino) による 3 次元計測を行い, (IV)区間では 2 次元電磁流速 計（KENEK 社製：VM-802H）による計測を行った.

\section{3. 実験結果および考察}

本試験では，計測地点より上流区間において十分に境 界層が発達するよう，また，下流区間においては石碩に よる低下背水やゲートによる堰上背水の影響が計測地点 まで及ばないよう以下のように試験区間を設定した。

- 群体試験時 : 計測地点から上流側に $2.4 \mathrm{~m}$ ，下流側に $1.5 \mathrm{~m}$ の区間に石碩を敷設（写真-2 左）.

-上流端試験時 : 計測地点から上流側に $2.4 \mathrm{~m}$ の区間に 厚さ $2 \mathrm{~mm}$ 程度の人工芝を敷設, 下流側に $2.8 \mathrm{~m}$ の区間に 石碩を敷設（写真-2 右).

紙面の都合上図には示していないが，計測地点上下流 における水深がほぼ一様であることを確認した，次に， 護岸ブロックの試験法 ${ }^{8}$ に準じて, 境界層が十分に発達し ているかの確認を行う。群体敷設状態で流量 $70 \ell / \mathrm{s}$ 通水 時の計測断面における実測流速 $u$ の分布と式(4)に示す 粗面対数則との比較を図-4に示寸.

$$
\frac{u}{u_{*}}=5.75 \log _{10} \frac{z}{k_{s}}+8.5
$$

ここに, $z$ : 連結石碩平均高 $h_{0}$ からの距離, $k_{s}$ : 相当粗 度 (抗力より求めた $u$ *を用いて, 平均流速公式より算出) である.

図より，u/u* は粗面対数則に概ね従っており，計測地 点において境界層の発達したほぼ一様な流れが形成され ていることを確認した。

\section{（1）抗力 $\cdot$ 揚力係数の結果と考察}

連結石碩に働く時間平均流体力 $D, L$ と石碩周辺の流 れの概況を図-5, 図-6に示寸. なお，透過型を図中の中 抜きマーカーで，不透過型を塗りつぶしマーカーで示し ている.
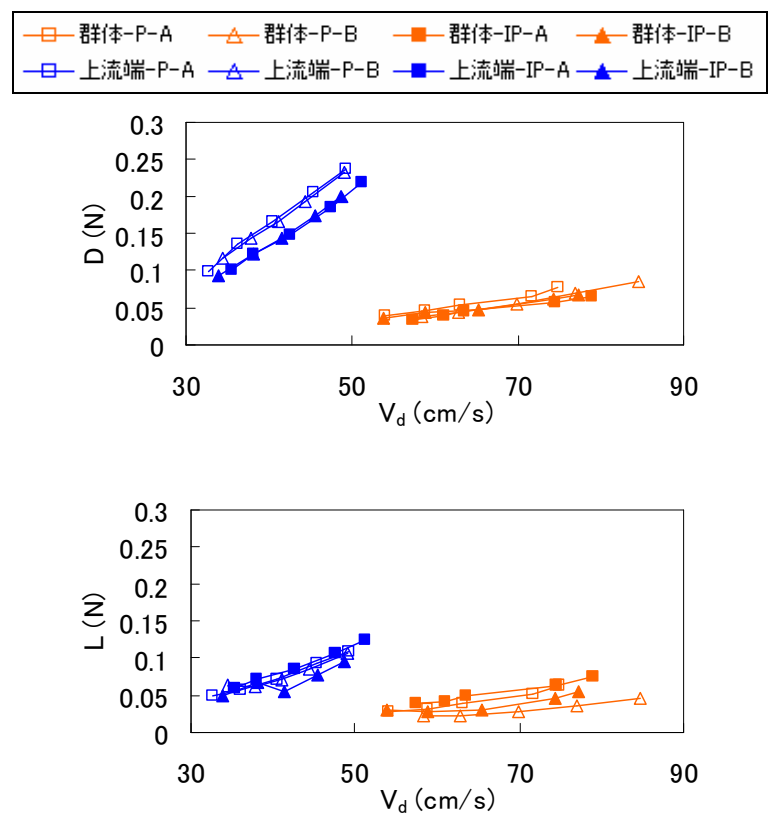

図-5 流体力
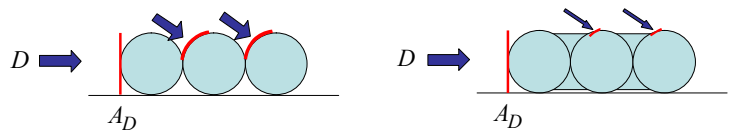

（a）透過型・不透過型の構造の違いによる抗力の違い
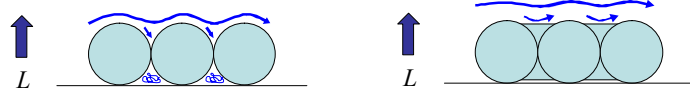

（b）揚力に影響する周辺流れの概況 図-6 石碟周辺の流れの概況

\section{a）群体試験}

抗力係数 $C_{D}$ および揚力係数 $C_{L}$ を図-7 に示す. 図中 の点線は透過型の平均值を, 実線は不透過型の平均值を 表している. 図より， $C_{D}$ は透過型の方が不透過型より も大きいことが分かる. ここで, 図-5 に示寸流体力 $D$ を 見ると，透過型の方がやや大きな流体力が作用している ことが分かる. これは，図-6(a)に示寸ように，透過型の 方が不透過型よりも抗力 $D$ を受け易い構造をしている からであると言える。 また，抗力作用面積は透過型，不 透過型による差異はほとんどない. よって, 抗力 $D$ によ る違いが直接的に抗力係数の違いに反映されたものと言 える.これより， $C_{D}$ については透過型，不透過型によ る違いを考慮する必要がある. 一方, 図-7 の揚力係数 $C_{L}$ は透過型, 不透過型による差は $C_{D}$ と比べて半分程度と かなり小さくなった. ここで，図-5に示寸流体力 $L$ を見 ると不透過型の方が透過型より同程度かやや大きいこと が分かる.これは，図-6(b)に示寸ように，透過型は石碩 間に空隙を有しているため，石碩上下面の圧力差が開放 されるのに対し，不透過型は空隙を有さないため石碩上 下面に圧力差が生じることが原因と考えられる. しかし， 揚力係数 $C_{L}$ については, 揚力作用面積が透過型の方が 小さくなることが影響し，結果的に，透過，不透過によ 

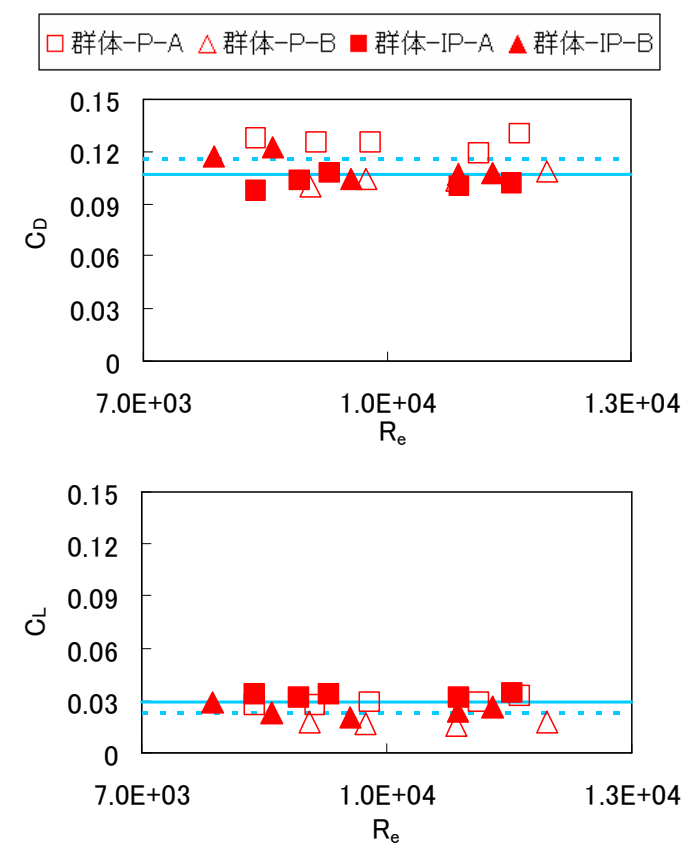

図-7 群体試験の抗力・揚力係数

\section{る差が現れなかったと言える.}

よって, $C_{D}$ は透過型が 0.12 , 不透過型が $0.11, C_{L}$ は 透過型, 不透過型の違いが小さかったことを考慮して, 平均值である 0.026 を得た。

\section{b）上流端試験}

抗力係数 $C_{D}$ および揚力係数 $C_{L}$ を図-8 に示す. 図よ り, $C_{D}$ については群体試験と同様の傾向が見られ，そ の理由も同様のものと考えられる. 一方， $C_{L}$ について は透過型，不透過型による差異は見られない，また，揚 力 $L$ の差も見られない.

よって $C_{D}$ は透過型が 0.92 , 不透過型が $0.79, C_{L}$ は透 過型，不透過型全ての平均值である 0.13 を得た.

\section{（2）破壊に関する検討 ${ }^{9}$}

連結石砶を実河川に敷設するに当っては, 図-9 に示寸 (a) めくれ，(b) 滑動，(c) 抜け出しの3つの破壊モデルに 関して検討する必要がある。ここでは，破壊駆動力と抵 抗力の比による破壊指数を求め, 連結石礫の群体設置時, 上流端設置時の安全性について検討寸る.

まず，破壊現象は，鬼束ら ${ }^{10}$ が指摘しているように， 時間平均された流体力ではなく, 瞬間的な流体力による 影響に依存するため, 瞬間的な流体力を把握することが 必要となる. 図-10に代表的な例として, 群体-P-A と上 流端-P-A の $D, L, M$ について，それぞれの瞬間流体 力 $F^{\prime}$ を時間平均流体力 $F$ で無次元化したヒストグラム の例を示した. 図中の実線は, 標準偏差 $F_{\sigma}$ を用いて式(5) で表される正規分布の確率密度関数である.

$$
f\left(\frac{F^{\prime}}{F}\right)=\frac{1}{\sqrt{2 \pi} F_{\sigma}} \exp \left(-\left(\frac{F^{\prime}-F}{F}\right)^{2} / 2 F_{\sigma}^{2}\right)
$$

図より，作用流体力の変動はほぼ正規分布に従ってい
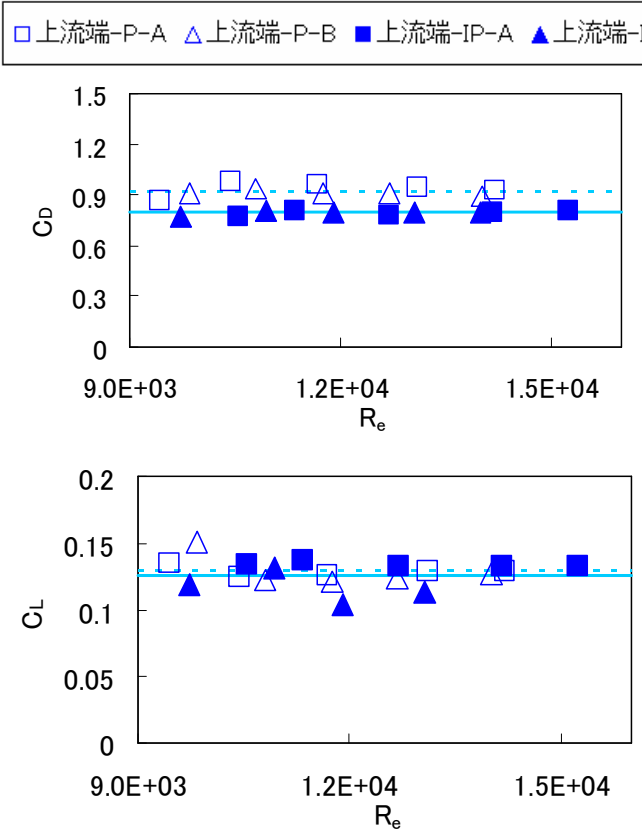

図-8上流端試験の抗力 $\cdot$ 揚力係数

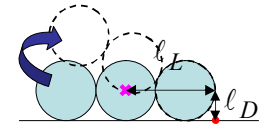

(a) めくれ $\left(F_{M}\right)$

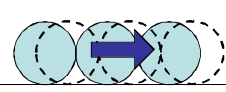

(b) 滑動 $\left(F_{D}\right)$
ることがわかる．このことは，実際の設計の際には，正 規分布を仮定して流体力の変動を推定できることを示し ている．また，石碩には最大で平均流体力 $F$ の 2.0 倍程 度の瞬間流体力 $F^{\prime}$ が作用している. 本来であれば, 時間 平均流体力 $F$ の夕ならず標準偏差 $F_{\sigma}$, 安全率を用いて 変動流体力を割り増しして石碩の安定性を検討する必要 がある.しかし，石碩に対する安全率の設定等の基淮が 明確でないことにより, 以下では石磼に作用する流体力 として時間平均流体力 $F$ を用いることとする.

(a)，(b)，(c)それぞれに対する破壊駆動力と抵抗力の比 による破壊指数 $F_{M}, F_{D}, F_{L}$ を次式によって求めた.

$$
\begin{gathered}
F_{M}=\left(D \cdot \ell_{D}+L \cdot \ell_{L}\right) / W \cdot \ell_{L} \\
F_{D}=D / \mu W \\
F_{L}=L / W
\end{gathered}
$$

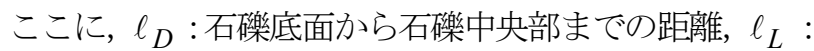
石碩下流端から石碩中央部までの距離, $W$ : 石碩の水中 自重， $\mu: 0.65$ である. なお，抗力・揚力の作用位置に ついては，実験結果より算出した力の作用線が，全試験 において連結石碩中心もしくは，それより下流側を通る ことが確涩されたため，安全側である石砶中心位置とした。

その結果を図-11 に示寸. 図より，本実験条件下での 破壊指数は, 群体, 上流端共に $F_{L}<F_{M}<F_{D}$ の順で大 きくなることがわかった．しかし，群体や上流端設置時 には，下流に隣接する連結石碩が当該連結石磎の滑動を 抑制するため，めくれに対する破壊の危険性が最も大き 

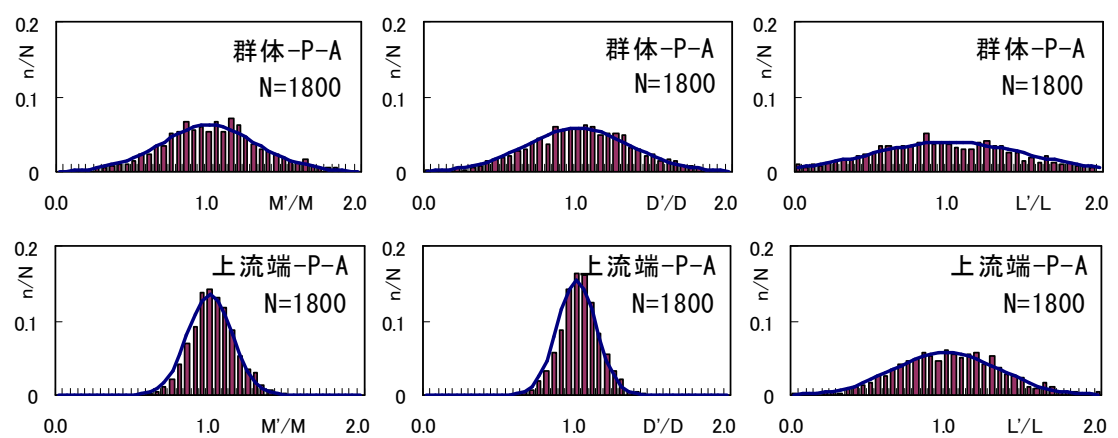

図-10 ヒストグラムと確率密度関数

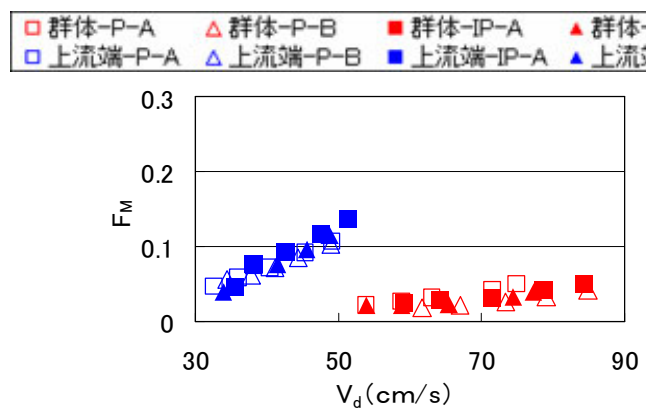

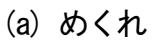

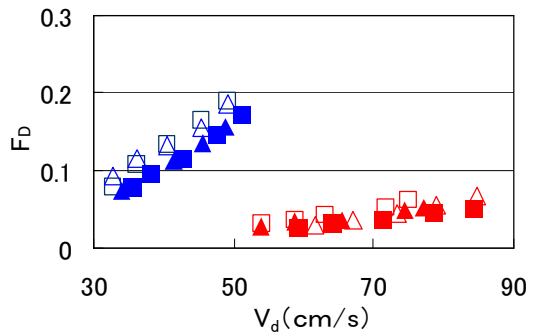

(b) 滑動

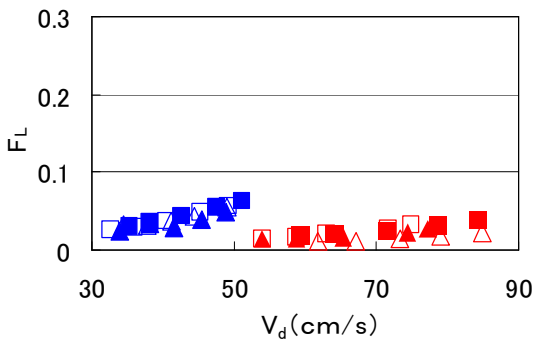

(c) 抜け出し

図-11 破壊指数

くなる．群体と上流端を比較すると，当然ではあるが, 上流端に設置される連結石碩の破壊に対する危険性がか なり大きくなることがわかる.

\section{（3）流れ場の特性}

\section{a) 相当粗度}

図-12 は群体試験時の平均流速 $V_{m}$ に対する相当粗度 $k_{s}$ の変化である. 透過型，不透過型それぞれの平均值は 約 $12 \mathrm{~cm}, 10 \mathrm{~cm}$ であり, それぞれ連結石砶突起高 $h_{b}$ $\left(h_{a}-h_{0}\right)$ の 7.7 倍，6.8 倍となった. 若干ではあるが 透過型の方が大きくなっている. これは，透過型の有す る石礫間の空間の存在による流れの乱れが影響している ものと考えられる． 林 ${ }^{11)}$ は六脚ブロックの相当粗度は突

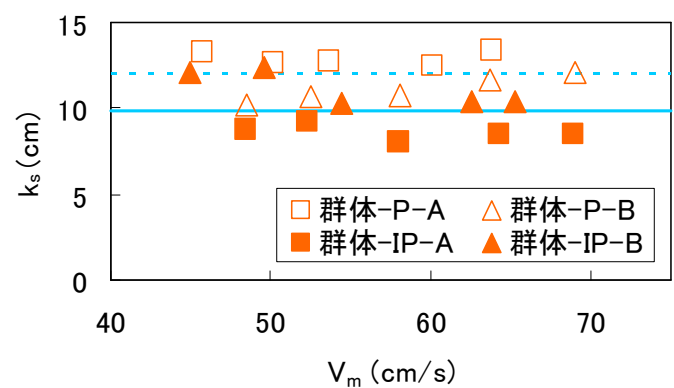

図-12 $V_{m}$ に対する $k_{s}$ の変化

起高さの約 1.6 倍であるとし, 富永 ${ }^{12)}$ は栈粗度の場合, 相対栈間隔（栈粗度の間隔/粗度高さ）が 10 前後で，相 当粗度は突起高さの 4 6.5 倍となると報告している.こ れらと比較すると, 石硯による流速低減効果が大きいこ とがわかる，これは，自然石の個々の異なった形状や凹 凸のばらつきによる効果により石碟上部の流れの乱れが かなり大きくなったことが原因と考えられる．また，本 研究では，水深に対する相当粗度が半分以上とかなり大 きい結果となった。これについては，林 ${ }^{11}$ の研究や山本 ら ${ }^{13)}$ による実験結果においても，本実験結果と同様に半 分程度あるいはそれ以上という結果も示されている.

b) 流速変動

図-13, 図-14 は主流方向，鉛直方向の流速成分の標準 偏差の分布を表したものである. 図より，主流方向の流 速変動は，石礫間，石礫直上で大きく，鉛直方向のそれ は，石礫直上から $z=8.5 \mathrm{~cm}$ 付近までが大きくそれより 上層では小さくなることがわかる. また, 各測定点の流速 分布を用いて式(2)より求めた相当粗度の平均は $8.7 \mathrm{~cm}$ で あった。（摩擦速度は群体透過型試験時の抗力から求め た. ) このことから, 石砅による乱れの影響範囲と相当粗 度の間には相関が認められる。

\section{c）流速原点位置}

表-3 は，式(4)の $z$ を $z_{01}$ を原点とした高さとし， $u$ と $\log _{10} z$ の関係を片対数紙にプロットし, 境界層発達区域 内においてプロットした流速の傾きが $5.75 u * （ u *$ は群 体透過型設置・流量 $50 \ell / \mathrm{s}$ 時の抗力より算出） と等しく なるように求めた流速原点位置 $z_{01}$ と, 河床付近の 2 点 の流速分布を外挿することにより求めた河床からの $z_{02}$ である. 表-3 より，石礫間の谷の部分へ流れが流入し $\mathrm{m}-\mathrm{m}$ 上で流速原点が小さくなることがわかる. また，対 

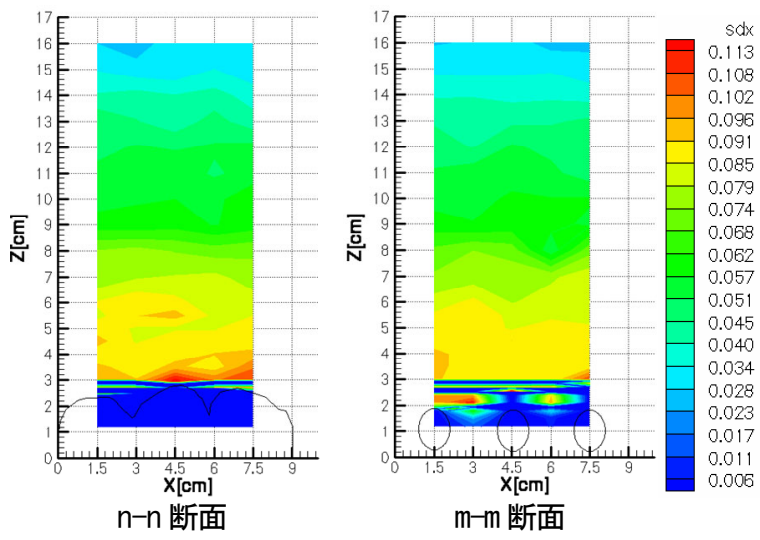

図-13 流下方向 $(x)$ の標準偏差 $(Q=50 \ell / s)$
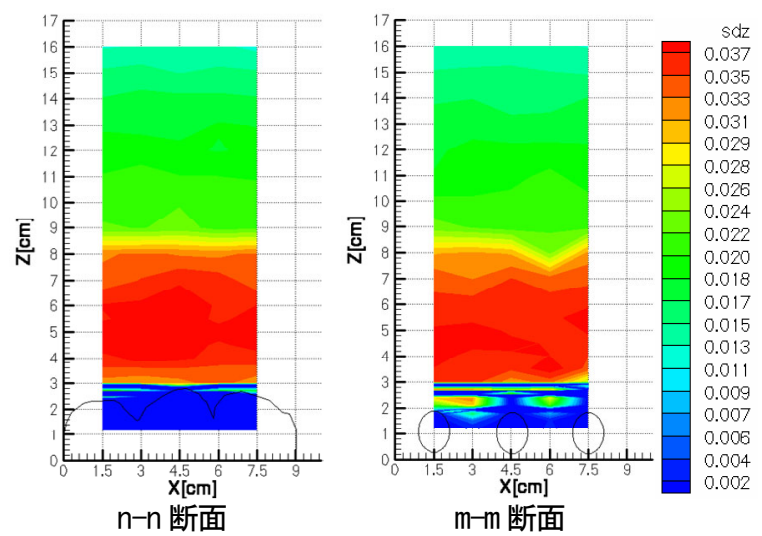

図-14 鉛直方向 $(z)$ の標準偏差 $(Q=50 \ell / s)$

数則，外挿それぞれの平均值は，いずれも連結石碟平均 高 $h_{0}: 1.41 \mathrm{~cm}$ よりも大きい. 外挿については, 礫の隙間 に当たる $\mathrm{m}-2, \mathrm{~m}-4$ では $h_{0}$ とほぼ同程度である．護岸ブ ロックの試験法 ${ }^{8)}$ では, 流速原点位置を平均高さ $h_{0}$ に設 定しているが，本研究では，流速原点位置がそれよりも 若干大きな值となった. また, 算出した $z_{01} ， z_{02}$ を図-4 の連結石礫中央上の流速分布と対数則との比較に反映し た結果, 最も対数側に相関しているのは $h_{0}$ であることが 確認された. しかし，これは限られた実験条件下での結 果であるため，流速原点位置については，今後さらに検 討寸る必要があると考える.

\section{4. 結論}

本研究は, 連結石碩の群体・上流端における抗力・揚 力係数を実験的に検討した. また，めくれ・滑動・抜け 出しに対する破壊抵抗について検討した. さらに群体試 験透過型においては, 流速の挙動を実験的に検討した. 以下に，得られた知見について示寸.

1) 連結石碟の群体・上流端設置時の抗力・揚力係数を明 らかにした。

2) 群体設置時にはめくれ破壊に対寸る検討を行う必要 がある，また，上流端に設置する石礫の破壊の検討が重 要である.

3) 連結石碩の相当粗度は突起高の数倍程度になる. 透過
表-3 流速原点位置 (単位 : $\mathrm{cm}$ )

\begin{tabular}{|c|c|c|c|c|c|}
\hline case & $z_{01}$ & $z_{02}$ & case & $z_{01}$ & $z_{02}$ \\
\hline $\mathrm{n}-1$ & 1.67 & 2.35 & $\mathrm{~m}-1$ & 1.69 & 1.88 \\
\hline $\mathrm{n}-2$ & 2.20 & 2.10 & $\mathrm{~m}-2$ & 1.50 & 1.41 \\
\hline $\mathrm{n}-3$ & 1.92 & 2.87 & $\mathrm{~m}-3$ & 1.56 & 2.45 \\
\hline $\mathrm{n}-4$ & 2.30 & 2.49 & $\mathrm{~m}-4$ & 1.56 & 1.50 \\
\hline $\mathrm{n}-5$ & 2.38 & 2.65 & $\mathrm{~m}-5$ & 2.47 & 2.78 \\
\hline
\end{tabular}

平均值: 対数則 $1.93 \mathrm{~cm}$, 外挿 $2.25 \mathrm{~cm}$

連結石磎平均高 $1.41 \mathrm{~cm}$

型の連結石踩の相当粗度の方が不透過型よりも大きくな る.

4) 流速変動は, 流下方向は石礫間や直上で, 鉛直方向は 石磁上部で大きくなり, 主流方向の変動成分が卓越する ことが確認された。

5) 流速原点位置は石碩頂点や谷間で異なり, その平均值 は連結石硯平均高よりも若干大きくなるが，連結石礫平 均高が最も対数則に従っていることが確認された.

本実験により，連結石碩の基本的な水理特性が明らか にされた。しかし，実際の設計に際しては，石硯周辺の 乱れ強度をどの程度見積もるかが重要である. 今後は, 堰直下流部や水制周辺，跳水などによる乱れ強度の影響 もさらに検討する予定である.

\section{参考文献}

1) 前野詩朗，道奥康治，森永智，大西利典：自然石を用いた 堰の水理特性，水工学論文集，第 46 巻, pp.493-498, 2002.

2) 前野詩朗，道奥康治，森永智，大西利典 : 捨石堰の破壊機 構のモデル化, 水工学論文集, 第 47 巻, pp.781-786, 2003.

3) 前野詩朗, 道奥康治, 加瀬瑛斗, 菊池慶太 : 個別要素法を 用いた捨石堰の破壊予測，水工学論文集，第 49 巻, pp.787-792, 2005.

4) 山本太郎, 長谷川和義, 浅利修一 : 連結された 2 個の䃇に 対寸る限界掃流力の評価について, 水工学論文集, 第 49 巻, pp.919-924, 2005.

5) 山本太郎, 長谷川和義, 浅利修一: 河床に設置された連結 磂工の安定性と破壊過程について, 水工学論文集, 第 50 巻, pp.955-960, 2006.

6) 山本太郎, 長谷川和義, 浅利修一 : 複数の礫が連結される ことによる流失限界の向上効果と掃流力評価について，土 木学会論文集, No.810/II-74, pp.31-42, 2006.

7) 前野詩朗, 藤原実咲, 富田晃生, 山村 明, 忰熊公子 : 連 結石碩の流体力評価に関寸る研究, 水工学論文集, 第 51 巻, pp.679-684, 2007.

8) (財)土木研究センター:護岸ブロックの水理特性試験法マニ ユアル(第 2 版), 2003.

9) 国土開発技術研究センター編 : 護岸の力学設計法, 山海堂, 1999.

10) 鬼束幸樹, 秋山壽一郎，重枝未玲，中川達矢，尾関弘明 : 斜水路下流部に配置された円筒形ブロックを用いた跳水制 御に関寸る実験的研究，応用力学論文集 Vol.9, pp. 846-852, 2006.

11) 林健二郎 : 大きな突起高と空隙を有する護岸ブロックに作 用する流体力と流れに関する研究，歴史的工法及び自然工 法を用いた河川環境の評価と保全に関する研究，プロジェ クト 1-1-2

12) 富永晃宏 : 栈粗度の相対栈間隔が開水路の乱流構造に及ぼ 寸影響, 水工学論文集, 第 36 巻, pp.163-168, 1992

13) 山本晃一，林健二郎，関根正人，藤田光一，田村正秀，西 村晋, 浜口憲一郎 : 護岸ブロックの抗力・揚力係数、および 相当粗度の計測方法について, 水工学論文集, 第 44 巻, pp.1053-1058, 2000.

(2007.9. 30 受付) 